\title{
THE EFFECT OF METABOLIC ALKALOSIS, HYPOTENSION AND INHIBITORS OF CARBONIC ANHYDRASE ON FLUID SECRETION BY RAT TESTES
}

\author{
B. P. SETCHELL AND B. W. BROWN
}

Department of Biochemistry, A.R.C. Institute of Animal Physiology, Babraham, Cambridge, and C.S.I.R.O., Division of Animal Physiology, The Ian Clunies Ross Animal Research Laboratory, Prospect, N.S.W., Australia

(Received 3rd February 1971, accepted 16th April 1971)

\begin{abstract}
Summary. Fluid secretion by rat testes was estimated from the gain in fluid content after efferent duct ligation. Fluid secretion was reduced by metabolic alkalosis induced by intravenous infusions of sodium acetate or bicarbonate but unaffected by the infusion of similar amounts of sodium as sodium chloride. Hypotension had no effect on fluid secretion nor did inhibitors of carbonic anhydrase given by mouth. However, acetazolamide injected intravenously and ethoxzolamide injected intraperitoneally decreased fluid secretion. The results support the theory that fluid secretion is an active process.
\end{abstract}

\section{INTRODUCTION}

The secretion of fluid by the testes of rats has been demonstrated by measuring the fluid increase after efferent duct ligation, EDL (Setchell, 1970a), by collecting fluid from a cannula in the rete testis, and by micropuncture of the seminiferous tubules (Tuck, Waites, Young \& Setchell, 1969; Tuck, Setchell, Waites \& Young, 1970). A number of studies in the ram have suggested that the secretion is an active process, not a passive filtration; one piece of evidence for this was the decrease in flow of fluid from the rete testis after infusions of acetazolamide (Setchell, 1970b). The aim of the present studies was to obtain further information on the process of fluid secretion in the testis, by examining in rats the effects of acetazolamide and other inhibitors of carbonic anhydrase, metabolic alkalosis and hypotension.

\section{MATERIALS AND METHODS}

Animals

Wistar strain rats, weighing between 100 and $200 \mathrm{~g}$, were used. Under light ether anaesthesia, one testis was exposed through a small mid-line abdominal incision, the efferent ducts were ligated and the testis was returned to the scrotum. In some rats, the ventral tail vein was also exposed and cannulated with a tapered PVC cannula $(0.2 \mathrm{~mm}$ i.d., $0.5 \mathrm{~mm}$ o.d. at its smaller end, 
Dural Plastics, Dural, N.S.W., Australia). The rats were allowed to recover in a constraining cage, which also held the rats during intravenous infusion (Brown, 1969). Twenty-four hours later, the rats were anaesthetized again with ether, and both testes were removed, weighed and dried to determine the total water content. The fluid secreted was expressed as the ratio of the water content of the EDL testis to that of the contralateral control testis (Setchell, 1970a). Two Soay rams weighing 19 and $24 \mathrm{~kg}$ and three Clun Forest wethers weighing between 28 and $38 \mathrm{~kg}$ were also used. They were kept in metabolism cages and allowed unrestricted access to pasture hay.

\section{Drugs and infusions}

Experiment 1. To produce metabolic alkalosis, aqueous sodium acetate $(10 \%$ $\left.\mathrm{w} / \mathrm{v} \mathrm{CH}{ }_{3} \mathrm{COO} \mathrm{Na}, 0.03 \mathrm{ml} / \mathrm{min}\right)$ or sodium bicarbonate $\left(6.4 \% \mathrm{w} / \mathrm{v} \mathrm{NaHCO}_{3}\right.$, $0.048 \mathrm{ml} / \mathrm{min}$ ) was infused for $24 \mathrm{hr}$ into the tail vein of eleven and five rats, respectively, with a peristaltic pump (Technicon, Chauncey, New York). Similar doses of sodium as sodium chloride $(7.15 \% \mathrm{NaCl}, 0.03 \mathrm{ml} / \mathrm{min})$ and similar volumes of physiological saline $(0.9 \% \mathrm{NaCl}, 0.048 \mathrm{ml} / \mathrm{min})$ were infused into another five and nine rats, respectively, for $24 \mathrm{hr}$. Sodium acetate $(2.6 \mathrm{ml} / \mathrm{min})$ and sodium bicarbonate $(4 \mathrm{ml} / \mathrm{min})$ were also infused, each into two wethers (weighing 28 and $38 \mathrm{~kg}$ ), to observe changes in blood $\mathrm{pH}$ measured with a Radiometer electrode Type G297 and K497 (Radiometer, Copenhagen) after $15 \mathrm{~min}, 1,2,3 \frac{1}{2}, 5$ and $7 \mathrm{hr}$. Blood $\mathrm{pH}$ was also measured in two rats receiving an infusion of sodium acetate and in two receiving sodium bicarbonate after 1,2 and $24 \mathrm{hr}$.

Experiment 2. Hexamethonium bromide $(10 \% \mathrm{w} / \mathrm{v}$, May \& Baker) was diluted to $2 \mathrm{mg} / \mathrm{ml}$ in physiological saline and infused at a rate of $0.048 \mathrm{ml} / \mathrm{min}$ into four rats for $24 \mathrm{hr}$. Towards the end of the infusion, the rats were again anaesthetized and one carotid artery was cannulated for the measurement of blood pressure, with a mercury manometer. In preliminary experiments in four other rats, the mean blood pressure was measured at intervals during a similar infusion.

Experiment 3. Methazolamide (Neptazane, Lederle), acetazolamide (Diamox, Lederle) and ethoxzolamide (Cardrase, Upjohn) were given as suspensions in water ( $10 \mathrm{mg}$ in $1 \mathrm{ml}$ ) by stomach tube, $5 \mathrm{hr}$ before and immediately preceding EDL; the testes were removed $24 \mathrm{hr}$ later. In Exp. 3b, acetazolamide (10 mg as the sodium salt in $0.5 \mathrm{ml}$ ) was injected intravenously into a jugular vein of four rats lightly anaesthetized with ether, four rats were given methazolamide $(25 \mathrm{mg})$ by mouth, four were given ethoxzolamide $(20 \mathrm{mg})$ by mouth and four were left as controls at the time of EDL and the testes removed $5 \mathrm{hr}$ later. In Exp. 3c, ten rats were given acetazolamide $(10 \mathrm{mg}$ as the $\mathrm{Na}$ salt in $0.5 \mathrm{ml}$ ) intravenously, ten rats were given $0.5 \mathrm{ml} 0.9 \% \mathrm{NaCl}$ intravenously, ten rats were given ethoxzolamide (10 $\mathrm{mg}$ in $0.2 \mathrm{ml}$ acetone) intraperitoneally and ten rats were given $0.2 \mathrm{ml}$ acetone intraperitoneally at the time of EDL and the testes removed $5 \mathrm{hr}$ later. In Exp. 3d, twelve rats were given three intraperitoneal injections each of $10 \mathrm{mg}$ ethoxzolamide in $0.2 \mathrm{ml}$ acetone at $8 \mathrm{-hr}$ intervals, the first immediately after EDL; the testes were removed $24 \mathrm{hr}$ after EDL. Seven controls were similarly treated with acetone. Urine was collected 
from each rat to see how long the diuretic action of ethoxzolamide persisted. In Exp. 3e, four rats anaesthetized with pentobarbitone sodium and two conscious rams were given acetazolamide as the sodium salt $(200 \mathrm{mg} / \mathrm{kg}$ intravenously) and the blood $\mathrm{pH}$ measured 15, 30,60 and 120 min later.

\section{Metabolic alkalosis (Exp. 1)}

\section{RESULTS}

Fluid secretion by the testis was drastically reduced by the induction of metabolic alkalosis, either with sodium acetate or sodium bicarbonate, whereas the infusion of similar amounts of sodium as sodium chloride had no effect (Text-fig. 1). The $\mathrm{pH}$ of the blood was increased to between 7.67 and 7.70

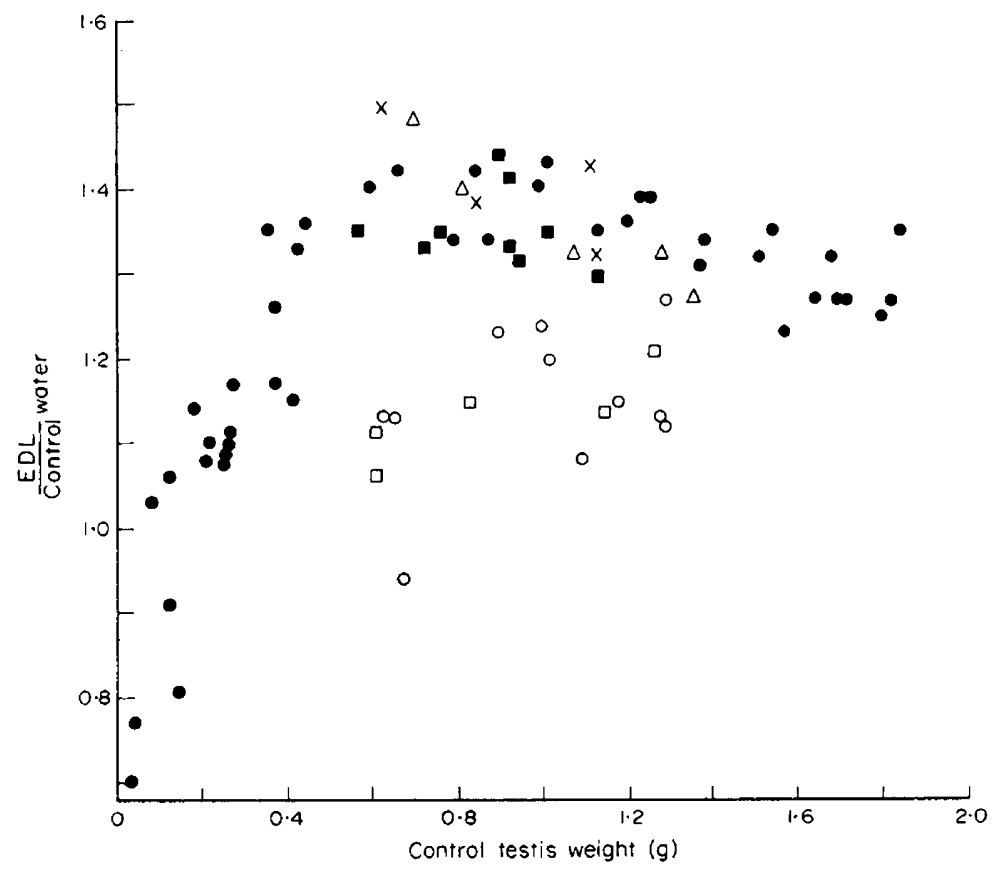

TEXT-FIG. 1. The effect in rats of metabolic alkalosis, induced by the infusion of sodium acetate $(0)$ or sodium bicarbonate ( $\square$ ), and the lack of effect of the infusion of similar amounts of sodium as sodium chloride $(\Delta)$ or of equivalent volumes of physiological saline ( $\square$ ) or of a hypotensive drug, hexamethonium bromide $(x)$ on testicular fluid secretion, here given as the ratio of the water content ( $\mathrm{g}$ water/g dry matter) of testes with the efferent ducts ligated (EDL) for $24 \mathrm{hr}$ to that of the contralateral control testes. Values for control rats receiving no infusion $(\bullet)$ are taken from Setchell (1970a). Doses are given in the Methods section.

within $1 \mathrm{hr}$ of beginning the infusion and remained at this level in both sheep and rats. The haemoglobin content of the blood and the haematocrit remained normal.

Hypotension (Exp. 2)

Fluid secretion by the testis was similar, whether the mean blood pressure was normal at 125 to $150 \mathrm{~mm} \mathrm{Hg}$ in control rats or reduced by hexamethonium to about $75 \mathrm{~mm} \mathrm{Hg}$ at the end of the infusion (Text-fig. 1). In the preliminary . 
experiments, it was found that mean blood pressure fell from normal values to between 70 and $80 \mathrm{~mm} \mathrm{Hg}$ within $2 \mathrm{hr}$ and remained steady in this range for the rest of the $24 \mathrm{hr}$.

Carbonic anhydrase inhibitors (Exp. 3) (see Table 1)

Inhibitors of carbonic anhydrase, when given by mouth, had no effect on fluid secretion over $24 \mathrm{hr}$ by rat testes. However, when acetazolamide was injected intravenously, there was a reduction in fluid secretion which was

TABLE 1

EFFECT OF VARIOUS INHIBITORS OF GARBONIC ANHYDRASE ON THE RATIO OF THE WATER CONTENT OF TESTES WITH THE EFFERENT DUGTS LIGATED TO THE CONTRALATERAL GONTROL TESTES

\begin{tabular}{|c|c|c|c|c|c|}
\hline & $\begin{array}{c}\text { Method of } \\
\text { administration }\end{array}$ & $\begin{array}{c}\text { Time after } \\
E D L \\
(h r)\end{array}$ & $\begin{array}{c}\text { EDL/control } \\
\text { water ratio }\end{array}$ & S.E. of mean & $\begin{array}{l}\text { No. of } \\
\text { animals }\end{array}$ \\
\hline $\begin{array}{l}\text { Exp. 3a } \\
\text { Acetazolamide } \\
\text { Ethoxzolamide } \\
\text { Methazolamide } \\
\text { Control }\end{array}$ & $\begin{array}{l}\text { By mouth } \\
\text { By mouth } \\
\text { By mouth } \\
\text { By mouth }\end{array}$ & 24 & $\begin{array}{l}1 \cdot 366 \\
1 \cdot 341 \\
1 \cdot 388 \\
1 \cdot 378\end{array}$ & $\begin{array}{l}0.022 \\
0.025 \\
0.010 \\
0.023\end{array}$ & $\begin{array}{l}5 \\
5 \\
5 \\
5\end{array}$ \\
\hline $\begin{array}{l}\text { Exp. 3b } \\
\text { Acetazolamide } \\
\text { Methazolamide } \\
\text { Ethoxzolamide } \\
\text { Control }\end{array}$ & $\begin{array}{l}\text { Intravenous } \\
\text { By mouth } \\
\text { By mouth } \\
\text { By mouth }\end{array}$ & 5 & $\begin{array}{l}1 \cdot 085 \\
1 \cdot 108 \\
1 \cdot 108 \\
1 \cdot 105\end{array}$ & $\begin{array}{l}0.009 \\
0.012 \\
0.012 \\
0.009\end{array}$ & $\begin{array}{l}4 \\
4 \\
4 \\
4\end{array}$ \\
\hline $\begin{array}{l}\text { Exp. 3c } \\
\text { Acetazolamide } \\
\text { Control } \\
\text { Ethoxzolamide } \\
\text { Control }\end{array}$ & $\begin{array}{l}\text { Intravenous } \\
\text { Intraperitoneal } \\
-\end{array}$ & 5 & $\begin{array}{l}1.067 \\
1.112 * * \\
1.071 \\
1.091 *\end{array}$ & $\begin{array}{l}0.0020 \\
0.0035 \\
0.015 \\
0.0044\end{array}$ & $\begin{array}{r}10 \\
10 \\
8 \\
10\end{array}$ \\
\hline $\begin{array}{l}\text { Exp. 3d } \\
\text { Ethoxzolamide }\end{array}$ & $\begin{array}{l}\text { Intraperitoneal } \\
\text { Three doses }\end{array}$ & 24 & $1 \cdot 275$ & 0.013 & 12 \\
\hline Control & - & & $1 \cdot 327^{*}$ & 0.013 & 7 \\
\hline
\end{tabular}

* $P<0.05 ;{ }^{* *} P<0.01$.

suggestive but not significant. In Exp. 3c, fluid secretion was significantly reduced in rats receiving acetazolamide intravenously or ethoxzolamide intraperitoneally. The effect of ethoxzolamide was also apparent in the rats treated every $8 \mathrm{hr}$ for $24 \mathrm{hr}$ in Exp. 3d. It is likely that the difference in this last experiment was due mainly to differences in secretion rates during the first $8 \mathrm{hr}$ after EDL and the first injection of ethoxzolamide, as it was only during this period that the drug produced an obvious diuresis. After intravenous injections of acetazolamide in four rats or two rams, blood $\mathrm{pH}$ either showed no change or fell slightly, as is normal for rats anaesthetized with pentobarbitone sodium (Exp. 3e).

\section{DISGUSSION}

The observations that fluid secretion by the rat testis is decreased during metabolic alkalosis and after injections of inhibitors of carbonic anhydrase, but 
unaffected by a reduction in blood pressure, is further evidence that the secretion of fluid is an active process. Similar evidence for the lack of effect of blood pressure was also found using the isolated perfused ram testis (Linzell \& Setchell, 1969) but as the blood flow through this preparation was two to three times that in vivo, it seemed desirable to obtain further evidence in vivo. It could be argued that blood flow and pressure within the organ itself rather than systemic blood pressure would be the determining factors. However, blood flow through the testis does not appear to be autoregulated (Linzell \& Setchell, 1969) and changes in systemic blood pressure would therefore probably lead to similar changes in mean blood pressure and flow within the testis.

Changes in blood pressure would be expected to affect a process involving filtration, but metabolic alkalosis and inhibitors of carbonic anhydrase would have no effect on filtration. Any reductions they caused would be due to interference with processes involving active secretion. Metabolic alkalosis also reduces the secretion of cerebrospinal fluid in dogs (Oppelt, Maren, Owens \& Rall, 1963) and infusions of sodium acetate stopped the flow of rete testis fluid in two rams (Setchell \& Linzell, 1968); this was also probably due to metabolic alkalosis as similar infusions of sodium acetate in sheep in the present experiments substantially increased the blood $\mathrm{pH}$.

Intravenous acetazolamide also reduced the flow of rete testis fluid in rams (Setchell, 1967; Setchell \& Linzell, 1968), and it is difficult to explain why oral doses of the inhibitors did not also cause a reduction in flow since they should have been sufficient to give almost complete inhibition of carbonic anhydrase. Similar oral doses of inhibitors cause marked falls in the production of aqueous humour and cerebrospinal fluid (see Maren, 1967). The lack of effect of oral doses on testicular fluid secretion in the rat could be because the effect is too transient; in the ram, where continuous measurement of fluid production is possible, secretion is only depressed for about 30 min after a single injection. Consequently, we may be attempting to measure very small changes in water gain after EDL. However, rats injected intravenously with acetazolamide showed a small reduction in fluid production, when there was no effect in others given inhibitors by mouth. This suggested that the effects of the injected acetazolamide may have been due to the alkalinity of the solution injected rather than to the specific inhibition of the enzyme, as acetazolamide can be dissolved for injection only if the $\mathrm{pH}$ of the solution is 9 or more. However, the amounts involved were not sufficient to cause significant changes in blood $\mathrm{pH}$ either in rams or rats, and similar decreases were seen after intraperitoneal injections of ethoxzolamide dissolved in acetone, so this explanation is probably not correct. Further work is needed to resolve these differences but the present studies provide additional evidence that fluid secretion by the testis is an active process and not simple filtration.

\section{ACKNOWLEDGMENTS}

We are grateful to Mrs M. D. Collyer, Mr M. C. Duggan and Mr A. R. Reid for their skilled assistance and to Lederle Laboratory Division, Upjohn Pty Ltd and May \& Baker Ltd for supplying the drugs used. 


\section{REFERENCES}

Brown, B. W. (1969) A simple technique for continuous intravenous infusion in the conscious rat. 7. Inst. Anim. Tech. 20, 4.

Linzerc, J. L. \& Setchell, B. P. (1969) Metabolism, sperm and fluid production of the isolated perfused sheep and goat testis. 7. Physiol., Lond. 201, 129.

Maren, T. H. (1967) Carbonic anhydrase: chemistry, physiology and inhibition. Physiol. Rev. 47, 595.

Oppelt, W. N., Maren, T. H., Owens, E. S. \& Rall, D. P. (1963) Effects of acid-base alterations on cerebrospinal fluid production. Proc. Soc. exp. Biol. Med. 114, 86.

Setchell, B. P. (1967) Fluid secretion by the testis. F. Reprod. Fert. 14, 347.

SETCHELL, B. P. (1970a) The secretion of fluid by the testes of rats, rams and goats with some observations on the effect of age, cryptorchidism and hypophysectomy. F. Reprod. Fert. 23, 79.

Setchell, B. P. (1970b) Testicular blood supply, lymphatic drainage and secretion of fluid. In: The Testis, p. 101. Eds. A. D. Johnson, W. R. Gomes and N. L. VanDemark. Academic Press, New York.

Setchell, B. P. \& Linzeld, J. L. (1968) The effect of some drugs, hormones and physiological factors on the flow of rete testis fluid in the ram. F. Reprod. Fert. 16, 320.

Tuck, R. R., Setcheld, B. P., Waites, G. M. H. \& Young, J. A. (1970) The composition of fluid collected by micropuncture and catheterization from the seminiferous tubules and rete testis of rats. Pfügers Arch. ges. Physiol. 318, 225.

Tuck, R. R., Waites, G. M. H., Young, J. A. \& Setchell, B. P. (1969) Composition of fluid secreted by the seminiferous tubules of the rat collected by catheterization and micropuncture techniques. Aust. 7. exp. Biol. med. Sci. 47, P32. 